\title{
GLUTATHIONE CYCLE IN DIQUAT NEUROTOXICITY: ASSESSED BY INTRASTRIATAL PRE-TREATMENT WITH GLUTATHIONE REDUCTASE
}

\author{
DJURDJEVIC D*, DJUKIC MIRJANA**, NINKOVIC MILICA*, STEVANOVIC IVANA*, \\ JOVANOVIC MARINA* and VASIC UNA*** \\ *Institute for Medical Research, Military Medical Academy, Belgrade, Serbia \\ **University of Belgrade, Faculty of Pharmacy, Belgrade, Serbia

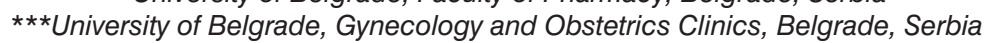

(Received 1 ${ }^{\text {st }}$ December 2012)

Diquat (DQ) neurotoxicity mechanisms are unknown, although, it's systemic toxicity is mediated by free radical reactions. The role of glutathione cycle was assessed by glutathione reductase (GR) applied in the pre-treatment of $D Q$ poisoning. Wistar rats were used and tested compounds were administered intrastriatally (i.s.) in one single dose. Total glutathione (tGSH), glutathione disulfide (GSSG) and glutathione peroxidase (GPx) were measured in the vulnerable brain regions (VBRs) (striatum, hippocampus and cortex), at 30 minutes, 24 hours and 7 days post treatment.

Results from the intact and the sham operated groups were not statistically different. Rapid spatial spreading of oxidative stress was confirmed in the examined VBRs..

Mortality (30-40\%, within 24hrs) and signs of lethargy were observed in the $D Q$ group. Activity of GPx activity was elevated and GSSG/GSH was higher in the examined VBRs during the experiment, compared to the controls. The i.s. pre-treatment with GR achieved neuroprotective role against $D Q$ induced neurotoxicity, based on animal survival, absence of lethargy and decreased GPX activity and GSSG/GSH in the examined VBRs during the experiment, compared to the $D Q$ group. Our results confirmed that oxidation of GSH was the reason for the reduced antioxidative defense against $D Q$ neurotoxicity.

Key words: diquat, glutathione, glutathione disulfide, glutathione peroxidase, glutathione reductase, neurotoxicity

\section{INTRODUCTION}

Misuse of pesticides, such as diquat (DQ) (1, 1'-dimethyl-4, 4'-bipyridinium), can lead to excessive contamination of the environment. Diquat is extremely toxic to humans $\left(\mathrm{LD}_{50} 35 \mathrm{mg} / \mathrm{kg}\right.$ ) and animals (rats: $\mathrm{LD}_{50}$ is $110-150 \mathrm{mg} / \mathrm{kg}$ ), by all routes of exposure. Agriculture workers are professionally exposed to $D Q$ by inhalation and dermal route of administration. Target organs of DQ toxicity are GIT, 
liver and kidney (Stevens and Summer, 1991; Houzé et al., 1990; EXTOXNET 1993). It is known that $D Q$ passes across the blood-brain barrier (Kušić et al., 1974). Specific therapy of $D Q$ poisoning has not been established to date, thus symptomatic therapy is in use (Robbe III and Meggs, 2004). Clinical symptoms of $\mathrm{DQ}$ poisoning are severe diarrhoea associated with disorders of water metabolism; and as for central nervous system (CNS) effects, it was confirmed that lethargy and general depression are the most commonly seen symptoms, although some authors have reported tremors and convulsions (EXTOXNET, 1993). Mechanism of Dq neurotoxcity is not clarified until now. It was reported that DQ passes the blood-brain barrier (BBB) (Kušić et al., 1974).

It is known that systemic toxicity of $D Q$ is mediated by increased production of free radicals, during its red-ox metabolism (Fuke et al., 1993; Wolfgang et al., 1991). In the presence of cytochrome P-450 reductase, $\mathrm{DQ}^{2+}$ (dication salt is in a commercial use) undergoes the one-electron reduction resulting in production of its radical form, $\mathrm{DQ}^{\cdot+}$ (stabilized by the conjugated double bond in the pyridine ring and quaternary nitrogen in another ring). In the reaction of $\mathrm{DQ}^{*+}$ with molecular oxygen $\left(\mathrm{O}_{2}\right)$, superoxide anion radical $\left(\mathrm{O}_{2}{ }^{-}\right)$and $\mathrm{DQ}^{2+}$ are formed, subsequently generating a chain of free radicals reactions, which are recognized as the main DQ cytotoxic effect (Fussella et al., 2011).

Brain tissue is particularly vulnerable to oxidative injury induced by red-ox compound, such as DQ (Djukic et al., 2007). Some parts of the brain, including: cortex, hippocampus and striatum are more vulnerable to oxidative/nitrosative stress (OS/NS) (Jovanovic et al., 1997).

Glutathione (GSH) is the principal endogenous antioxidant. Reactions in which GSH participates are reduction agent of lipid hydroperoxides and/or hydrogen peroxides $\left(\mathrm{H}_{2} \mathrm{O}_{2}\right)$, catalyzed by glutathione peroxidase (GPx); conjugations of thiols, nitroso compounds and metal ions; and formation of reactive thyil radicals (antioxidative, as well as, prooxidative nature of glutathione analogue radical forms were established) (Dringen, 2000; Wu et al., 2004; Meister, 1988; Ballatori, 2009; Douglas, 1987; Leaver and George, 1998; Mieyal, 2008; Smith, 2005; Kehrer, 1994). Depletion of GSH occurs in OS/NS. There is a growing evidence that GSH plays an important role in the detoxification of reactive oxygen species in OS related poisonings or diseases (Dringen, 2000; Chubatsua et al., 1992; Ninkovic et al., 2003; Ninkovic et al., 2008).

In reactions of lipid hydroperoxides $/ \mathrm{H}_{2} \mathrm{O}_{2}$ reduction by GPx, GSH (a donor of reducing equivalents) becomes oxidized to glutathione disulfide (GSSG). Several approaches have been undertaken to retain GSH at the level to achieve its antioxidative effect, such as: a) systemic administration of precursors for the biosynthesis of GSH (L-cysteine and/or N-acetylcysteine) which passes across biological membranes and the BBB; and b) given orally, GSH is ineffective because of its poor absorption from the digestive tract and/or poor ability to permeate through the membrane (Zeevalk et al., 2008; Sommer et al., 2000; Yoshimura et al., 1982). Recycling of GSSG back to GSH by glutathione reductase (GR) is essential physiological reaction to maintain required amount of GSH for its antioxidative role to be realised. 
Acta Veterinaria (Beograd), Vol. 63, No. 2-3, 159-175, 2013.

Djurdjevic D et al.: Glutathione cycle in diquat neurotoxicity:

assessed by intrastriatal pre-treatment with glutathione reductase

Enzymes are large molecules that do not cross the BBB (Banks, 2009). In order to examine the significance of GSH depletion at the expense of GSSG formation in $\mathrm{DQ}$ neurotoxicity we administered GR intrastriataly (i.s.). In this toxicological-experimental mechanistic study we tried: a) to ascertain what is the role of glutathione cycle in DQ neurotoxcity; and b) to examine whether neuroprotection of vulnerable brain regions (VBRs) (striatum, hippocampus and cortex) against harmful oxidative injury of $i$.s. administered DQ would be achieved by the i.s. pre-treatment with GR.

\section{MATERIALS AND METHODS}

\section{Animals}

The experimental animals were treated according to Guidelines for Animal Study, No. 282-12/2002 (Ethics Committee of the Military Medical Academy, Belgrade, Serbia and Montenegro). The experiments were performed on adult male Wistar rats (č 220g), randomly divided into two control groups (the intact group $n=8$, and the sham-operated, $n=24$ ) and three experimental groups $(n=24$, each) which were further subdivided into three subgroups $(n=8)$ according to the time of sacrificing. Conditions for rats housing: group of rats/cage, $t=232\} \mathrm{C}$, relative humidity $55 \pm 3 \%$, a light/dark cycle: $13 / 11$ hours, and had free access to standard pellet food and water. Before the beginning of the experiment, rats were adapted during 7 days.

\section{Experimental design}

Rats were anaesthetized intraperitoneally by sodium pentobarbital (45 mg/kg per body weight) before the i.s administration of the testing substances, as follows: the intact group (not treated, $n=8$ ), the sham-operated rats $(10 \mu \mathrm{L}$ of saline), $\mathrm{n}=24$; the GR group(GR, $15.63 \mathrm{U} / 10 \mu \mathrm{L}), \mathrm{n}=24$; the $\mathrm{DQ}$ group $(2.5 \mu \mathrm{g} \mathrm{DQ} / 10 \mu \mathrm{L}$, ie. $0.01 \mu \mathrm{M} / 10 \mu \mathrm{L}) \mathrm{n}=24$; and the $\mathrm{GR}+\mathrm{DQ}$ group (GR, $15.63 \mathrm{U} / 5 \mu \mathrm{L}$, immediately before $\mathrm{DQ}$ administration, $0.01 \mu \mathrm{M} / 5 \mu \mathrm{L}$ ), $\mathrm{n}=24$. Yeast GR was used in this study according to homology with sequences of rats and humans, substrate specificity, kinetics characteristic and substrate affinity (Cardoso et al., 2008; Prado et al. 2004; Ondaraza and Abney, 1970; Lindsay, 1995). Testing substances were administrated by Hamilton syringe as single doses in final volumes of $10 \mu \mathrm{L}$, which is insufficient to burden nerve tissue. To achieve accuracy of the testing substances injections we used a stereotaxic instrument for small laboratory animals (coordinates: $8.4 \mathrm{~mm}$ behind the bregma, $2.6 \mathrm{~mm}$ left from the midline suture and $4.8 \mathrm{~mm}$ ventral from dura) (König JFR, 1963). The animals were sacrificed by decapitation at 30 mins, $24 \mathrm{~h}$ and 7 days after the treatments. Biochemical parameters of OS were measured in the ipsiand contra- lateral side of the VBRs. To exclude the possibility whether mechanical injury causes OS in the VBRs, we compared OS parameters between the shamoperated and the intact groups. 
Reagents

All chemicals were of analytical grade. The following compounds were used in this study: Diquat - Galokson ${ }^{\circledR}(200 \mathrm{~g} / \mathrm{L})$ (Galenika - Zemun, Serbia); Sodium pentobarbital - Vetanarcol® $(0.162 \mathrm{~g} / \mathrm{mL})$ (Werfft - Chemie, Vienna, Austria); Glutathione reductase (EC 1.6.4.2), Type III, from yeast [9001-48-3], Sigma Chemical Co (St Luis, MO, USA) - highly refined suspension in $3.6 \mathrm{M}\left(\mathrm{NH}_{4}\right)_{2} \mathrm{SO}_{4}$, at $\mathrm{pH} 7.0 ; 2500 \mathrm{U} / 1.6 \mathrm{~mL}$ (9.2 mg prot/mL - biuret) $170 \mathrm{U} / \mathrm{mg}$ proteins (Note: 1 unit reduces $1 \mu \mathrm{mol}$ GSSG/min, $\mathrm{pH} 7.6$ at $\left.25^{\circ} \mathrm{C}\right)$; saline solution $(0.9 \% \mathrm{w} / \mathrm{v})($ Hospital Pharmacy Military Medical Academy, Belgrade, Serbia); glutathione, glutathione disulfide and nicotinamide adenine dinucleotide phosphate (NADPH) (Boehringer Corp. - London, UK); ethylenediaminetetraacetic acid - EDTA, 2vinylpyridine (Sigma Aldrich - Sr. Louis, USA); sodium phosphate $-\mathrm{Na}_{2} \mathrm{HPO}_{4}$, potassium dihydrogen phosphate - $\mathrm{KH}_{2} \mathrm{PO}_{4}$, 5,5-dithiobis-2-nitrobenzoic acid (DTNB), triethanol amine, sulfosalicylic acid (Merck - Darmstadt, Germany); Deionised water was prepared by the Millipore milli-Q water purification system (Waters - Millipore, Milford, MA, USA).

The tissue preparation

The tissue homogenates of the VBRs were prepared as described earlier (Gurd, 1974). After separation from the other brain regions, cortex, striatum and hippocampus were kept on ice during the whole procedure. Slices of the VBRs were transferred separately into cold buffered sucrose $(0.25 \mathrm{~mol} / \mathrm{L}$ sucrose, $0.1 \mathrm{mmol} / \mathrm{L}$ EDTA in sodium-potassium phosphate buffer, $\mathrm{pH} 7$ ). Aliquots (1 mL) were placed into a glass tube homogeniser (Tehnica Zelezniki Manufacturing, Slovenia). Homogenization was performed twice with a teflon pestle at $800 \mathrm{rpm}$ $(1,000 \times \mathrm{g})$ for $15 \mathrm{~min}$ at $4^{\circ} \mathrm{C}$. The supernatant was centrifuged at $2,500 \times \mathrm{g}$ for 30 min at $4^{\circ} \mathrm{C}$. The resulting precipitate was suspended in $1.5 \mathrm{~mL}$ of deionised water. Solubilisation of subcellular membranes in hypotonic solution was performed by constant mixing for $1 \mathrm{~h}$ using a Pasteur pipette. Thereafter, homogenates were centrifuged at 2,000 $\times \mathrm{g}$ for $15 \mathrm{~min}$ at $4^{\circ} \mathrm{C}$ and the resulting supernatant was used for analysis. Total protein concentration was estimated by Lowry method (Lowry et al., 1951).

\section{Measurements}

Glutathione, total and oxidized disulfide form, and glutathione peroxidase were measured in both sides of the striatum, hippocampus and cortex, after the treatments at $30 \mathrm{~min}, 24 \mathrm{hrs}$ and 7 days.

Total glutathione (tGSH) and oxidized glutathione (GSSG)

For determination of total glutathione (tGSH) and GSSG, brain tissue was prepared in $10 \%$ sulfosalicylic acid. The tGSH and GSSG were then determined before and after masking of the GSH content of the samples with 2-vinylpyridine [homogenates were incubated with $1 \mathrm{M}$ 2-vinylpyridine solution $(10 \mu \mathrm{L} / \mathrm{mL}$ of homogenate) for two hours, at room temperature] and 3.4\% triethanol amine to mask GSH) followed by the enzymatic recycling assay by using 5,5-dithiobis-2nitrobenzoic acid (DTNB) (36.9 mg DTNB in $10 \mathrm{~mL}$ of methanol) which reacts with 
Acta Veterinaria (Beograd), Vol. 63, No. 2-3, 159-175, 2013.

Djurdjevic $\mathrm{D}$ et al.: Glutathione cycle in diquat neurotoxicity:

assessed by intrastriatal pre-treatment with glutathione reductase

aliphatic thiol compounds in TRIS-HCl buffer (0.4 M, pH-8.9) and produces yellow colour due to p-nitrophenol anion. Intensity of colour was measured spectrophotometrically at 412 nm (Anderson, 1986; Mølck, Friis, 1997; Griffith, 1980; Shaik and Mehvar, 2006; Tretter et al., 2003). The results of tGSH and GSSG were expressed as nmol per $\mathrm{mg}$ of proteins. The ratio GSSG/GSH was considered for the interpretation of the results.

Glutathione peroxidase (GPx)

This method is based on the indirect determination of GPx activity by spectrophotometric measurement of NADPH consumption at $340 \mathrm{~nm}$. Briefly, enzyme GPx catalyzes the reduction of (lipid) hydroperoxides to (alcohols) $/ \mathrm{H}_{2} \mathrm{O}$ using reducing equivalents of $\mathrm{GSH}$, which itself then becomes oxidized. Furthermore, regeneration of depleted GSH occurs throughout the reduction of GSSG to GSH, catalyzed by the enzyme GR, which consumes NADPH as a donor of reducing equivalents. Reduction of every mole of GSSG requires one mole of NADPH (Maral et al., 1977). The results were expressed as U GPx per mg of proteins.

Statistical analysis

Data analysis was performed using Statistica software version 7.0 (Stat Soft, Inc.). Parameters of OS were presented graphically for the ispilateral and in tabular form for the contralateral side of the VBRs. Data are shown as mean \pm standard deviation. Parameters of OS measured at different time points within each group were compared by the independent Student's t-test. OS parameters for the same time point, but between the groups, were compared using ANOVA with the Tukey's post hoc test. Differences were considered statistically significant when for $p<0.05^{*}, p<0.01^{* *}$ and $p<0.001^{* * *}$.

\section{RESULTS}

The results obtained for the ipsilateral side of the VBRs (Graphs $1-4$ ) were almost identical to the contralateral side (data not shown). No statistical differences were observed between the intact group and the sham-operated groups. Lethality of the animals (30\% - 40\%) within 2-3 hours after awakening from anesthesia was observed only in the DQ group. Lethargy was observed only in that group, as well.

Total glutathione (tGSH), oxidised glutathione GSSG, reduced glutathione (GSH) and ratio GSSG/GSH

Mainly, tGSH is calculated as: tGSH $=\mathrm{GSH}+\mathrm{GSSG}$, but some authors calculate it differently, such as: $\mathrm{tGSH}=\mathrm{GSH}+1 / 2 \mathrm{GSSG}$, although rarely; and/or even as: $\mathrm{tGSH}=\mathrm{GSH}+2$ GSSG (Anderson, 1986; Griffith, 1980; Mølck and Friis, 1997; Shaik and Mehvar, 2006; Tretter et al., 2003). The ratio GSSG/GSH is presented graphically (Graph 3). 
In the DQ group, the level of tGSH was in the range of control values. Only, in the GR+DQ group, it was significantly lower in the examined VBRs, at $7^{\text {th }}$ days $(p<0.05)$, compared to the controls (Graph 1$)$.

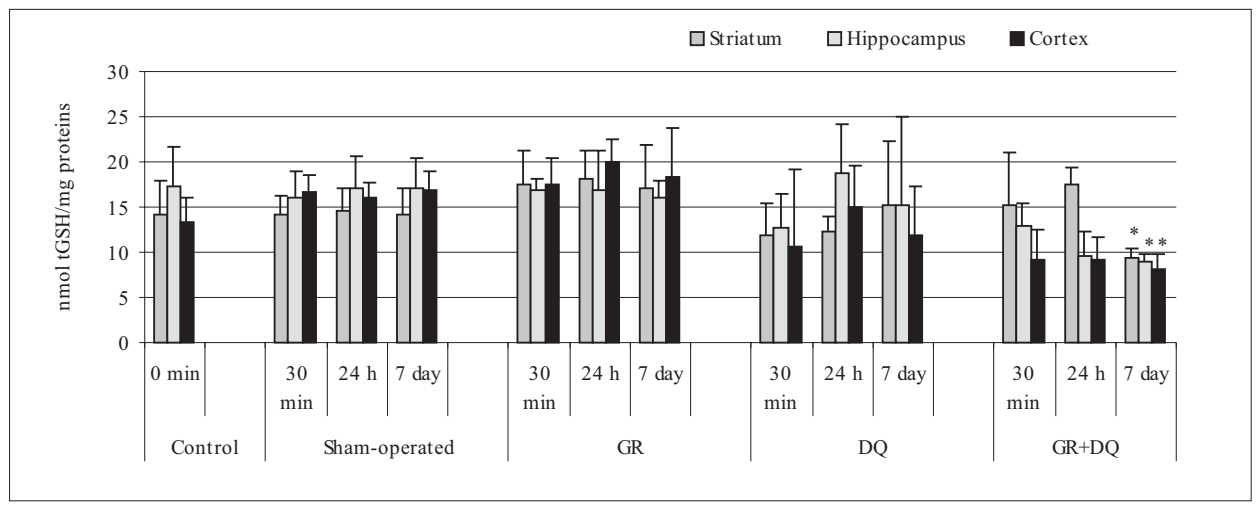

Figure 1. Total glutathione (tGSH) in ipsilateral vulnerable brain regions (striatum, hippocampus and cortex) of rats after single intrastriatal administration of diquat (the $D Q$ group), glutathione reductase (the GR group) and glutathione reductase in the pretreatment of diquat administration (the GR + DQ group).

Presented parameter of antioxidative defence: Total glutathione (tGSH) is expressed as: $\mathrm{nmol} \mathrm{tGSH} / \mathrm{mg}$ proteins. ${ }^{*}$ See the experimental conditions presented in the subsection: Experimental design. Values are means $\pm S D(n=8$ rats per each time point: 30 min, 24 hrs, 7 days).

One-way ANOVA followed by post-hoc Tukey test were used for statistical analysis; $\mathrm{p}<0.05$ was considered as significant for the same time point. Statistically significant differences are marked as follows: $p<0.05\left(^{*}\right), p<0.01\left(^{* *}\right)$ and $p<0.001\left(^{* * *}\right)-$ compared to the control group; and: $p<0.05\left(\mathrm{dq}^{\star}\right), \mathrm{p}<0.01\left(\mathrm{dq}^{\star \star}\right)$ and $\mathrm{p}<0.001$ $\left(\mathrm{dq}^{\star \star \star}\right)$ - compared to the DQ group

Oxidized glutathione (GSSG) was statistically high in all VBRs during the experiment in the $\mathrm{DQ}$ group (increase was the highest at $30^{\text {th }}$ (striatum and cortex $p<0.01$; hippocampus $p<0.05$ ), with descending trend over time (at $24^{\text {th }}$ hrs: striatum and cortex $p<0.05$; hippocampus $p<0.01$; and at 7 days: hippocampus and cortex, $p<0.05)$. In the GR+DQ group, concentration of GSSG was statistically increased only in the cortex at $24^{\text {th }}$ hrs. Compared to the DQ group, values of GSSG were significantly different (lower), within $24 \mathrm{hrs}$ in the examined VBRs $(p<0.05)($ Graph 2$)$.

The ratio GSSG/GSH was significantly higher in all VBRs during the experiment in the DQ group emphasizing extremely high values within $24 \mathrm{hrs}$ (for the cortex, in particular) compared to the controls. In the GR+DQ group, values of the ratio GSSG/GSH were still significantly higher in all VBRs during the experiment, considering that at $30^{\mathrm{th}} \mathrm{min}$, those values are statistically lower compared to the DQ group (Graph 3). 
Acta Veterinaria (Beograd), Vol. 63, No. 2-3, 159-175, 2013.

Djurdjevic D et al.: Glutathione cycle in diquat neurotoxicity:

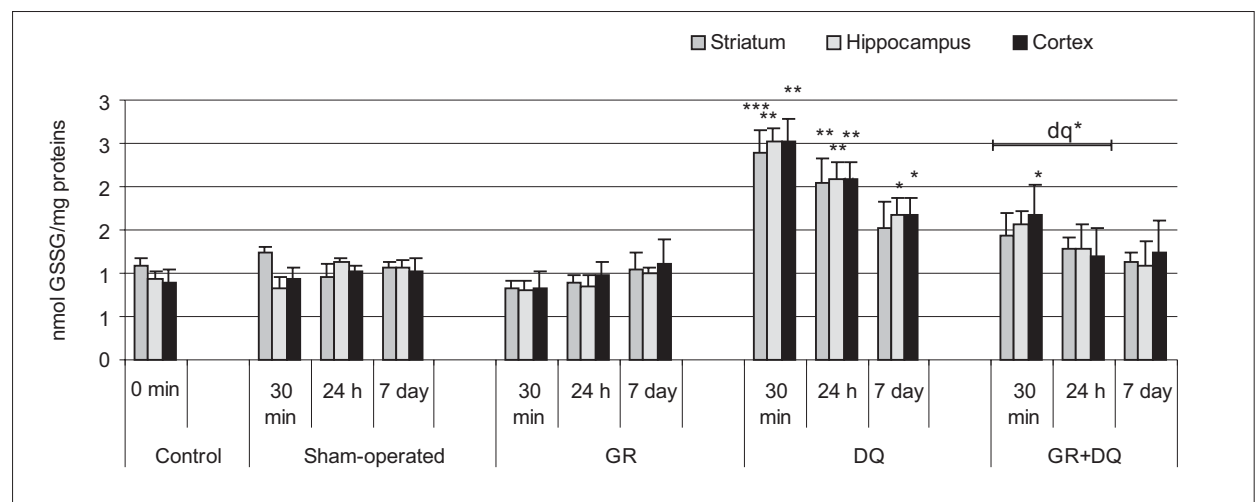

Figure 2. Glutathione disulfide (GSSG) in ipsilateral vulnerable brain regions (striatum, hippocampus and cortex) of rats after single intrastriatal administration diquat (the DQ group), glutathione reductase (the GR group) and glutathione reductase in the pretreatment of diquat administration (the GR + DQ group).

Product of GSH oxidation, glutathione disulfide is expressed as: nmol GSSG/mg proteins. *See the experimental conditions presented in the subsection: Experimental design. Values are means $\pm S D(n=8$ rats per each time point: 30 min, 24 hrs, 7 days).

One-way ANOVA followed by post-hoc Tukey test were used for statistical analysis; $p<0.05$ was considered as significant for the same time point. Statistically significant differences are marked as follows: $\left.\mathrm{p}<0.05\left(^{*}\right), \mathrm{p}<0.01{ }^{(* *}\right)$ and $\left.\mathrm{p}<0.001{ }^{(* * *}\right)-$ compared to the control group; and: $p<0.05\left(\mathrm{dq}^{\star}\right), p<0.01\left(\mathrm{dq}^{* \star}\right)$ and $p<0.001$ $\left(\mathrm{dq}^{\star \star *}\right)$ - compared to the DQ group

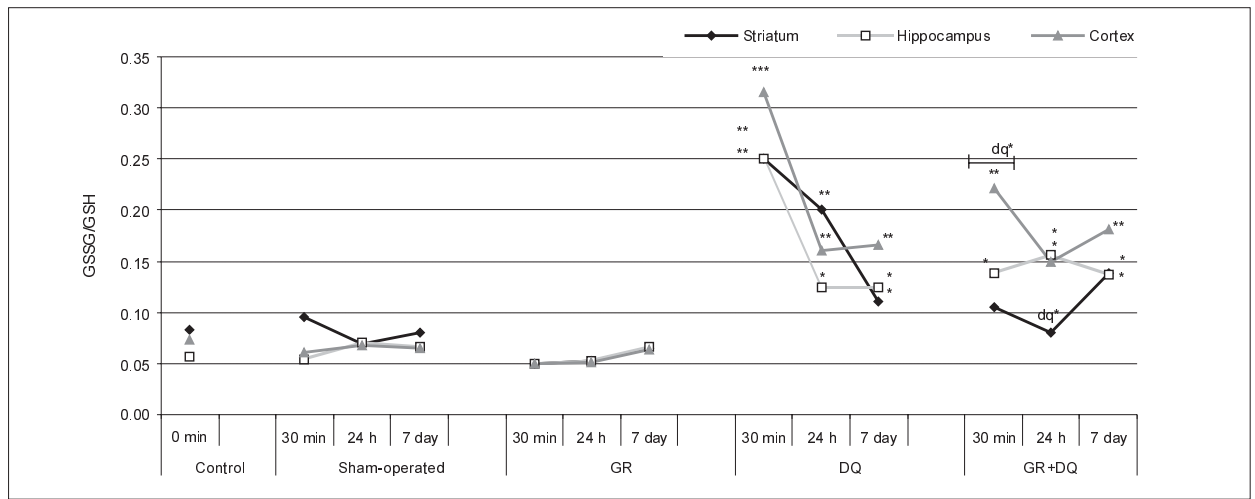

Figure 3. The ratio of GSSG/GSH calclulated for ipsilateral vulnerable brain regions (striatum, hippocampus and cortex) of rats after single intrastriatal administration diquat (the DQ group), glutathione reductase (the GR group) and glutathione reductase in the pretreatment of diquat administration (the GR + DQ group).

The relation between oxidized and reduced glutathione is presented as the ratio GSSG/GSH. The amount of reduced glutathione (GSH) was calculated by subtracting GSSG from tGSH for each sample. *See the experimental conditions presented in the subsection: Experimental design. Values are means $\pm S D(n=8$ rats per each time point: $30 \mathrm{~min}, 24 \mathrm{hrs}, 7$ days). 
One-way ANOVA followed by post-hoc Tukey test were used for statistical analysis; $p<0.05$ was considered as significant for the same time point. Statistically significant differences are marked as follows: $p<0.05\left(^{*}\right), p<0.01\left(^{* *}\right)$ and $p<0.001\left(^{* * *}\right)$ - compared to the control group; and: $p<0.05$ $\left(\mathrm{dq}^{*}\right), \mathrm{p}<0.01\left(\mathrm{dq}^{\star *}\right)$ and $\mathrm{p}<0.001\left(\mathrm{dq}^{\star * *}\right)$ - compared to the DQ group.

Glutathione peroxidase (GPx)

In the DQ group, GPx activity was significantly increased in the examined VBRs during the experiment $(p<0.05)$. Contrary, in the GR+DQ group, GPx activity was significantly reduced $(p<0.05)$ and additionally, significantly lower compared to the DQ group ( $p 0.05$ ), within $24 \mathrm{hrs}$, and in the hippocampus, at 7 days (Graph 4).

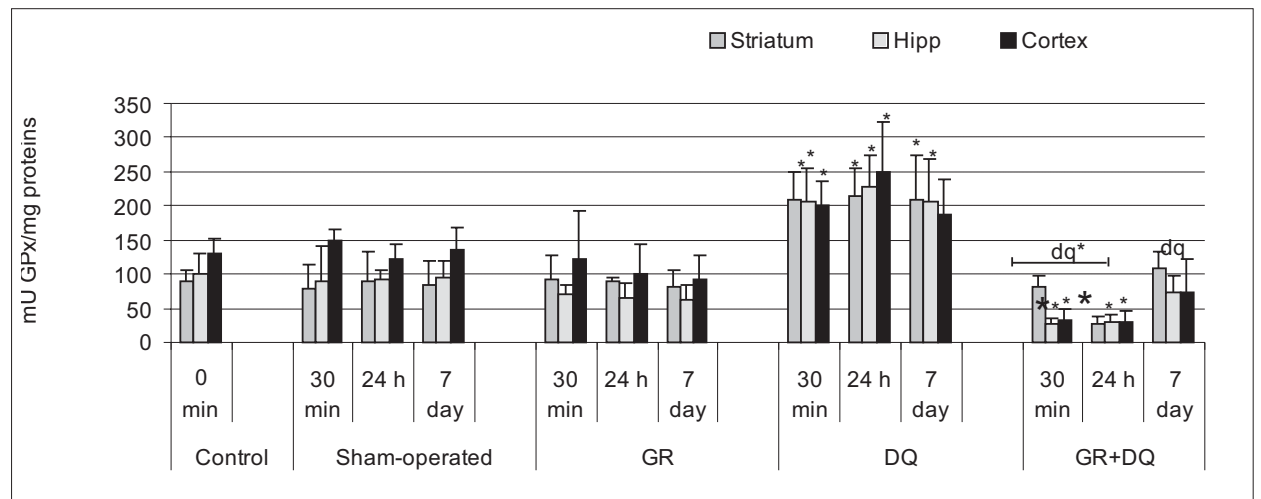

Figure 4. Activity of glutathione peroxidase (GPx) in ipsilateral vulnerable brain regions (striatum, hippocampus and cortex) of rats after single intrastriatal administration diquat (the DQ group), glutathione reductase (the GR group) and glutathione reductase in the pretreatment of diquat administration (the GR + DQ group).

Presented parameter of antioxidative defense: Activity of GPx is expressed as: $\mathrm{mU}$ GPx /mg proteins. *See the experimental conditions presented in the subsection: Experimental design. Values are means $\pm S D(n=8$ rats per each time point: 30 min, 24 hrs, 7 days).

One-way ANOVA followed by post-hoc Tukey test were used for statistical analysis; $p$ 0.05 was considered as significant for the same time point. Statistically significant differences are marked as follows: $\mathrm{p}<0.05\left(^{*}\right), \mathrm{p}<0.01\left(^{* *}\right)$ and $\mathrm{p}<0.001\left(^{* * *}\right)-$ compared to the control group; and: $p<0.05\left(\mathrm{dq}^{*}\right), p<0.01\left(\mathrm{dq}^{\star \star}\right)$ and $p<0.001$ $\left(\mathrm{dq}^{\star \star *}\right)$ - compared to the DQ group

\section{DISCUSSION}

For the first time, results of our study showed that i.s. administered GR, given in the pre-treatment of $D Q$ i.s. injection ascertained a neuroprotective role. Specifically, in the group of rats i.s. poisoned with $D Q$, signs of lethargy and mortality (30-40\%) after awakening from anesthesia, were observed within $24 \mathrm{hrs}$ of the treatment what was accompanied with initially (at the $30^{\text {th }} \mathrm{min}$ ) huge GSSG/GSH ratio and high activity of GPx. Though, with descending trend over time, GSSG/GSH stayed significantly elevated during the experiment in the 
Acta Veterinaria (Beograd), Vol. 63, No. 2-3, 159-175, 2013.

examined VBRs in the $D Q$ group. Contrary to that, in the GR+DQ group, all animals survived and there were no sings of lethargy Additionally, biochemical parameters of glutathione cycle showed that GSSG was in the range of controls but statistically lower compared to DQ group within $24 \mathrm{hrs}(\mathrm{p}<0.05)$ as it was seen for $\mathrm{GP}_{\mathrm{X}}$, with the difference that latter was significantly lower compared to the controls in all time points (except for the striatum at $30^{\text {th }}$ min and $7^{\text {th }}$ days, and hippocampus, at $7^{\text {th }}$ days). It was obvious that the pre-treatment with GR, weakened the DQ harmful effect on the examined brain regions (Graphs 1-4). It is still unknown the mechanism underlying these confirmed changes.

Results obtained from the intact and the sham operated groups were not statistically different, confirming that invasive i.s. route of administration does not influence the reliability of results. Also, a similar pattern of changes was observed within the examined VBRs, indicating fast spatial spreading of OS. By analogy with the studies of Corsanti, Beggeta and co-workers who reported about PQ nurotoxicity we designed our experiment to study the pathways of DQ neurotixicity (Widdowson et al., 1996). In our experiment, we injected i.s a dose of $\mathrm{DQ}(0.01 \mu \mathrm{mol} / 10 \mu \mathrm{L})$ to Wistar rats. Apparently, the applied dose was satisfactory to study the mechanisms of DQ neurotoxicity. Seven days is a period sufficient for recovery to be achieved, if reversible tissue damage occurred (Kang, 2009; McCormack et al., 2005; Widdowson et al., 1996).

Our results and observations showed that remarkable high GPx activity along with a huge peak of the ratio GSSG/GSH (within 30 mins of DQ i.s. administration) coincided with signs of lethargy and animals death (within 24 hrs of $i . s$. administration of $\mathrm{DQ}$ ) and is associated with significant oxidation of GSH (Graphs 1-4) (Elsayed, 1982). That could be explained by the DQ cytotoxic effect, ie. powerful oxidative metabolism of $\mathrm{DQ}$ and consequent enormous $\mathrm{O}_{2}$ deprivation. Compared to paraquat (PQ) (widely used herbicide, bipyridylium analogue of $D Q$ ), $D Q$ is a more powerful oxidant based on its redox potentials $\left(E_{0}{ }^{\prime}=-349 \mathrm{mV}\right.$ for $\mathrm{DQ}$ and $E_{0}{ }^{\prime}=-446 \mathrm{mV}$ for $\left.\mathrm{PQ}\right)$ and its intense oxidative metabolism probably underlies its harmful effects (Lewinson et al., 1984). Explicitly, $\mathrm{DQ}^{\cdot+}$ reacts with $\mathrm{O}_{2}$, forming $\mathrm{O}_{2}{ }^{--}$and $\mathrm{DQ}^{2+}$, thus triggers free radicals chain reactions and development of OS/NS, what was proofed by our previous study (submitted, but still not published data) (Grushenka et al., 1991; Fussella et al., 2011). Instantly launched antioxidative mechanisms were recognized with increased GPx activity and therefore a marked increase of GSSG, although tGSH was not significantly decreased at the time. It is known that in physiological conditions the extent of GSSG is neglected compared to GSH (Olafsdottir and Reed, 1988). Thus, for example in mitochondria, the ratio of GSSG/GSH (1:10) indicates a powerful oxidative metabolism in this cell compartment, which is also assembled with more intense GSH red-ox turnover than in the cytosol. Therefore, more intense oxidative metabolism requires more increased antioxidant protection (Richman and Meister, 1975). As mitochondria lack the enzymes for GSH synthesis, the mitochondrial GSH concentration is maintained constant via uptake from the cytosol (transport systems, which are stimulated by ATP and and ADP (Pastore et al., 2003). Cellular synthesis and consumption of GSH are balanced by its synthesizes (ATP dependent two-steps synthesis: the gGluCys 
synthetase uses glutamate and cysteine to form the dipeptide gGluCys, which is further combined with glycine in a reaction catalyzed by glutathione synthetase to generate GSH) and feedback inhibition of gGluCys synthetase by the endproduct GSH, at the intracellular level (Richman and Meister, 1975; Olafsdotti et al, 1988; Dringen, 2000).

Based on extremely increased peak of the GSSG/GSH at $30^{\text {th }}$ min of DQ i.s. poisoning (Graph 3), our study confirms that the GSH oxidation to GSSG is the dominant way of GSH depletion in $D Q$ neurotoxicity comparing to the other pathways of GSH depletion such as conjugation with proteins, NO, metals, etc. (Pastore et al., 2003). Steady state concentrations of $\mathrm{O}_{2}{ }^{-{ }^{-}}$and $\mathrm{DQ}^{2+}$ interfere the metabolism of glutathione forms such as: thiyl radical (GS ${ }^{*}$ ), thiolate anion (GS ${ }^{-}$) and conjugate of thiyl radical and thiolate [GSSG] ${ }^{\circ}$. Redox compounds, which radical forms are stabilized by the conjugated double bond, such as semiquinones $\left[\mathrm{Q}_{2}{ }^{-} / \mathrm{Q}^{2-}\right]$ and bipyridilium compounds $\left[\mathrm{DQ}^{2+} / \mathrm{DQ}^{\cdot+}\right]$, could be involved in the oxidation of $\mathrm{GS}^{-}$oxidation to $\mathrm{GS}^{*}$ (Fukushima et al., 1994; Nivière and Fontecave, 1955; Cadenas 1997). In the presence of $\mathrm{O}_{2}{ }^{--}$and $\mathrm{DQ}^{2+}$, oxidation of $\mathrm{GS}^{-}$to $\mathrm{GS}^{-}$could take two possible pathways: a) when $\left[\mathrm{DQ}^{2+}\right]_{\mathrm{SS}}$ or $\left[\mathrm{Q}_{2}{ }^{--}\right]_{\mathrm{ss}}>>\left[\mathrm{O}_{2}{ }^{--}\right]_{\mathrm{ss}}$, enzyme SOD favours oxidation of $\mathrm{GS}^{-}$to $\mathrm{GS}^{*}$; b) if $\left[\mathrm{DQ}^{2+}\right]_{\mathrm{ss}}$ or $\left[\mathrm{Q}_{2}{ }^{-}\right]_{\mathrm{ss}}<\left[\mathrm{O}_{2}{ }^{-}\right]_{\mathrm{ss}}$, then $\mathrm{GS}^{\cdot}$ formation is suppressed by SOD. Also, when $\left[\mathrm{DQ}^{2+}\right]_{\mathrm{ss}}$ or $\left[\mathrm{Q}_{2}{ }^{\circ-}\right]_{\mathrm{ss}}>>\left[\mathrm{O}_{2}{ }^{--}\right]_{\mathrm{ss}}$, enzyme SOD favors conjugation of thiyl radical with thiolate $\left(\mathrm{RS}^{\circ}+\mathrm{RS}^{-}=[\mathrm{GSSG}]^{\circ-}\right)$ and oxidation of [GSSG] ${ }^{\circ-}$ to GSSG ([GSSG] $]^{\cdot-}+\mathrm{O}_{2}=\mathrm{GSSG}+\mathrm{O}_{2}{ }^{--}$). Therefore, relative steady state concentrations of $\mathrm{O}_{2}$. and $\mathrm{DQ}^{2+}$ have an influence on cell red-ox state. These facts are also confirmed by the results referring to the high GSSG/GSH ratio in the DQ group (Graphs 3).

Thiyl radical enhances the lipid peroxidation because of its strong red-ox potential $\left(E^{\mathrm{O}} \mathrm{RS} \cdot / \mathrm{RSH}=+0.9 \mathrm{~V}\right)$ and easily reacts with free fatty acids: a) abstraction of hydrogen (rate of reaction is $\sim 10^{7} \mathrm{M}^{-1} \mathrm{~s}^{-1}$ ), b) addition to double bonds (rate of reaction is $\sim 10^{8} \mathrm{M}^{-1} \mathrm{~s}^{-1}$ ), when formed alkyl radical may react with $\mathrm{O}_{2}$ to form corresponding peroxyl radicals (Schafer, 2001). Obviously, depleted GSH and consequently reduced antioxidative defense is and was probably the crucial factor, besides $\mathrm{O}_{2}$ deprivation, for harmful outcome of $D Q$ i.s. poisoning of rats (Boonplueang, 2005). Importance of glutathione cycle in DQ neurotoxicity and its neuroprotective role is confirmed in our study by i.s. applying of GR.

Descending trend of GPx activity and decreasing of GSSG over time in the $D Q$ group, emphasize that the most deleterious effects occur immediately upon exposure to DQ, within $24 \mathrm{hrs}$, during immense red-ox metabolism of DQ that coincided with lethargy and mortality of animals. Biochemical parameters of antioxidative defense, such as GPx and GSSG/GSH, were recognized as very sensitive and the most responsive OS biomarkers of $D Q$ induced neurotoxicity.

Mammalian cells can deal with an increased GSSG/GSH ratio in several ways: synthesis of more GSH (using g-GCS), convertion of GSSG into GSH (using GR) or export of GSSG (Schafer, 2001). It is not known, what is the proportion between comprised elements of total thiols (refers to free glutathione forms: GSH and GSSG, and protein and/or NO-bound fractions) (Pastore et al., 2003). Positive outcome of i.s. administration of GR in the pre-treatment of DQ i.s. 
Acta Veterinaria (Beograd), Vol. 63, No. 2-3, 159-175, 2013.

poisoning, suggests the possibility that GSSG reduction occurs extracellularly, although it is known that it occurs within the cell, emphasizing that the fraction of "free" GSSG is considerable compared to total glutathione (Olafsdottir and Reed, 1988). Within this context, reduction of "free" GSSG back to GSH by GR deserves noteworthy attention, in sense that reduction by GR could prevent its conjugation with proteins, lipids, NO, metals, etc, and thus avoid/minimize damage of cells/ tissues.

Also, DQ neurotoxicity could be attributed to the formation of GS-NO (reaction of nucleophilic addition of GSH to substrate that have electrophilic functional group), catalyzed by GSH-S-transferase, which also explains the decrease of GPx activity (that uses GSH as a donor of reducing equivalents) (Noack $\mathrm{H}$ et al., 1999). Donors of NO could decrease intracellular glutathione (GSH) levels in lymphocytes by as much as 75\% (Berendji et al., 1999). Changed thiol-disulfide status of critical cysteines on enzymes, receptors, transport proteins, and transcription factors is recognized as an important mechanism of signal transduction and an important consequence of OS associated diseases (Mieyal et al., 2008). Additionally, GSSG directly activates N-methyl D-aspartate (NMDA) receptors and/or enhances its response, by which excitotoxicity becomes part of the overall response to DQ i.s. exposure (Boonplueang et al., 2005). Thus both, increased GPx activity followed by subsequent GSSG increase (significantly elevated GSSG/GSH within $24 \mathrm{hrs}$ ) possibly contribute to excitotoxicity via stimulation of NMDA receptors and subsequent release of glutamate, which coincided with rats mortality in the DQ group.

According to our previous study (submitted, but not published yet) DQ neurotoxicity is mediated by OS/NS. Ebadi and Sharma's showed (2003) that peroxynitrite anion $\left(\mathrm{ONOO}^{-}\right)$effectively inhibits enzymes in the mitochondrial respiratory chain followed by reduced ATP synthesis (Djukic et al., 2007; Ebadi and Sharma, 2003; Lestaevel et al., 2003). It is known that depletion of the sources of electrons and $\mathrm{H}^{+}$donors, such as NADPH and GSH, happens during OS/NS. Depletion of NADPH and activation of the hexose monophosphate shunt (HMPS), increased production of reactive oxygen specie's and oxidation of GSH to GSSG altogether contribute to $D Q$ cytotoxic effect and energy exhaustion eventually led to cell death (Tawara, 1996). Some redox-cycling compounds completely inhibit the activation of HMPS by inhibiting GR (Schraufstatter et al., 1985). However, there is no data specifically related to the inhibition of GR by DQ, but if we presume that it is possible, we can speculate that the GR pre-treatment procedure adopted by us could be one rationale more, for such experimental approach.

Almost equal values of OS parameters in the VBRs proved prompt and spatial spreading of oxidative deleterious effects of DQ (Cui et al., 2004; Halliwell, 2001). Primary damage to one part of brain tissue inevitably leads to subsequent disorders in other structures, as confirmed by our experiments. The anatomicalfunctional organization of these brain structures underlying equal propagation process of OS (Fukushima et al., 1994; Tawara et al., 1996). No significant variations of GSH levels between brain regions (cortex, hippocampus, striatum, midbrain, and cerebellum) were reported, although in here we reported the sequence by the amount of GSH level as follows: hippocampus > striatum > cortex 
in intact rats (differences were statistically insignificant), while there are some reports that slightly higher values of GHS were found in the cortex (Roušar et al., 2012). Although, striatum was the brain region that was targeted by i.s. injection of the testing substances in our experiment, the obtained results showed that red-ox balance was not significantly changed in this structure (sham operated vs. intact group).

Intrastriatal administration of GR itself does not exert any harmful effect (Graphs 1-4). Taking into consideration the above facts, it becomes obvious that tissues of the VBRs were protected by GR pre-treatment, most likely due to recycling of GSSG back to GSH (Graphs 1 - 4). It was shown that the antioxidative effect of GSH is crucial in neuro-protection of brain tissues against harmful effect of DQ mediated by OS/NS. The oxidation of GSH to GSSG is probably dominant way of GHS depletion in DQ induced neurotoxicity and main reason for reduced antioxidative defense against DQ harmful oxidative effect. Guided by the fact that GR does not pass across the cell membrane and/or the blood-brain barrier and further, we applied i.s. GR to enable extracellular/interstitial conversion of GSSG into the GSH. The mechanisms of GSH and/or its precursors or breakdown products transport of across the membranes and/or the blood-brain barrier is still unrevealed (Wade and Brady, 1981; Ennis et al., 1998; Kannan et al., 1990; 1992; 1996; 1999; Zlokovic et al., 1994; Favilli et al., 1997; Jain et al., 1991; Meister, 1991). Our study confirms that extracellularly recycled GSSG by GR, i.s. administered, contributes to increasing reuptake of GSH (tripeptide: $\gamma$-L-glutamylL-cysteinyl glycine) or its precursors or breakdown constituents (structure constituents: amino-acids in single or di-peptide form) into the cells of CNS, thus achieving the protective role.

\section{CONCLUSION}

In summary, GSH - mediated antioxidative response and oxygen starvation are probably critical pathophysiological pathways in an early stage of DQ i.s. induced neurotoxicity. The absence of lethargy and mortality in the group of rats pre-treated with GR indicated a neuroprotective role of i.s. administered GR.

Results of this study firstly indicate that the pre-treatment of i.s. injected GR accomplished the protective role against harmful i.s. DQ poisoning, probably due to extracellularly/interstitially GSSG recycling and sustaining of GSH at the level essential for its antioxidative role (by cell reuptake of extracellularly formed GSHcatalyzed reaction by i.s. injected GR). Our findings are very important and valuable in the scientific field of thiol-based redox regulation and signaling.

This work was supported by Grants from the Ministry of Education and Science, Republic of Serbia (Project No. III41018) and by the Ministry of Defense of the Republic of Serbia (Project No. MMA/0610/B.3). 
Address for correspondence:

Djurdjevic Dragan, PhD vet. med.

Institute for Medical Research

Military Medical Academy

Crnotravska 17

11000 Belgrade, Serbia

E-mail:vmaimi@eunet.rs

\section{REFERENCES}

1. Anderson ME, 1986, Tissue glutathione the DTNB-GSSG reductase recycling assay for total glutathione (GSH+1/2 GSSG), in: Greenwald RA editors, CRC Handbook of Methods for Oxygen Radical Reseach, Florida: CRC Press Inc, 317-23.

2. Ballatori N, Uzann-Krance SM, Marchan R, Hammond CL, 2009, Plasma membrane glutathione transporters and their roles in cell physiology and pathophysiology, Mol Aspects Med, 30, 1-2, 13-28.

3. Berendji D, Kolb-Bachofen V, Meyer KL, Kroncke KD, 1999, Influence of nitric oxide on the intracellular reduced glutathione pool: different cellular capacities and strategies to encounter nitric oxide-mediated stress, Free Radic Biol Med, 27, 773-80.

4. Boonplueang R, Akopian G, Stevenson FF, Kuhlenkamp JF, Lu SC, Walsh JP et al., 2005, Increased susceptibility of glutathione peroxidase-1 transgenic mice to kainic acid-related seizure activity and hippocampal neuronal cell death, Exp Neurol, 192, 1, 203-14.

5. Cadenas $E, 1997$, Physicochemical determinants of free-radical cytotoxicty, in: Walace KB, editor, Free Radical Toxicology, Taylor \& Francis, 115-39.

6. Cardoso LA, Ferreira ST, Hermes-Lima M, 2008, Reductive inactivation of yeast glutathione reductase by $\mathrm{Fe}(\mathrm{II})$ and NADPH, Comp Biochem Physiol Part A, 151, 313-21.

7. Chubatsua L, Gennarib M, Meneghin R, 1992, Glutathione is the antioxidant responsible for resistance to oxidative stress in V79 Chinese hamster fibroblasts rendered resistant to cadmium, Chem Biol Interact, 82, 1, 99-110.

8. Collinson PL, Dawes WI, 1995, Isolation, characterization and overexpression of the yeast gene, GLRI, encoding glutathione reductase, Gene, 156, 123-7.

9. Cui K, Luo X, Xu K, Murthy MRV, 2004, Role of oxidative stress in neurodegeneration: recent developments in assay methods for oxidative stress and Nutraceutical antioxidants, Prog Neuropsychopharmacol Biol Psychiatry, 28, 771-99.

10. Diquat, EXTOXNET, Extension Toxicology Network, Publication Date: (9/1993) http://pmepccecornelledu/profiles/extoxnet/metiram-propoxur/diquat-exthtm/

11. Djukic M, Curcic-Jovanovic M, Ninkovic M, Vasiljevic I, Jovanovic M, 2007, The role of nitric oxide in paraquat-induced oxidative stress in rat striatum, Ann Agric Environ Med, 14, 2, 247-52.

12. Djukic M, Curcic-Jovanovic M, Ninkovic M, Vasiljevic I, Jovanovic M, 2007, The role of nitric oxide in paraquat-induced oxidative stress in rat striatum, Ann Agric Environ Med, 14, 2, 247-52.

13. Douglas KT, 1987, Mechanism of action of glutathione-dependent enzymes, Adv Enzymol Relat Areas $\mathrm{Mol} \mathrm{Biol}, 59,103-67$.

14. Dringen $R, 2000$, Metabolism and functions of glutathione in brain, Prog Neurobiol, 62, 649-71.

15. Ebadi M, Sharma SK, 2003, Peroxynitrite and mitochondrial dysfunction in the pathogenesis of Parkinson's disease, Antioxid Redox Signal, 5, 319-35.

16. Elsayed N, Hacker A, Mustafa M, Kuehn K, Schrauzer G, 1982, Effects of decreased glutathione peroxidase activity on the pentose phosphate cycle in mouse lung, Biochem Biophys Res Commun, 104, 2, 564-9.

17. Ennis SR, Kawai N, Ren XD, Abdelkarim GE, Keep RF, 1998, Glutamine uptake at the blood-brain barrier is mediated by N-system transport, $J$ Neurochem, 71, 2565-73.

18. Favilli F, Marraccini P, lantomasi T, Vincenzini MT, 1997, Efect of orally administered glutathione on glutathione levels in some organs of rats: role of specific transporters, $\mathrm{Br} J$ Nutr, 78, 293-300. 
19. Fuke C, Ameno K, Ameno S, Kiriu T, Shinohara T, Ijiri I, 1993, In vitro studies of the metabolism of paraquat and diquat using rat liver homogenates-isolation and identification of the metabolites of paraquat and diquat, Nippon Hoigaku Zasshi, 47, 1, 33-45.

20. Fukushima T, Yamada K, Hojo N, Isobe A, Shiwaku K, Yamane Y, 1994, Mechanism of cytotoxicity of paraquat III The effects of acute paraquat exposure on the electron transport system in rat mitochondria, Exp Toxicol Pathol, 46, 437-41.

21. Fussella KC, Udasina RG, Grayb JP, Mishina V, Smithc P, Heckd DE, Laskine JD, 2011, Redox cycling and increased oxygen utilization contribute to diquat-induced oxidative stress and cytotoxicity in Chinese hamster ovary cells overexpressing NADPH-cytochrome P450 reductase, Free Radic Biol Med, 50, 7, 874-82.

22. Griffith OW, 1980, Determination of glutathione and glutathione disulfide using glutathione reductase and 2-vinylpyridine, Anal Biochem, 106, 207-12.

23. Grushenka HI, Jolly WR, Petry TW, 1991, Diquat-induced oxidative damage in hepatic microsomes: Effects of antioxidants, Free Radic Biol Med, 10, 6, 403-11.

24. Gurd JW, Jones LR, Mahler HR, Moore WJ, 1974, Isolation and partial characterisation of rat brain synaptic plasma membrane, $J$ Neurochem, 22, 281-90.

25. Halliwell $B, 2001$, Role of free radicals in the neurodegenerative diseases: therapeutic implications for antioxidant treatment, Drugs Aging, 18, 685-716.

26. Houzé P, Baud FJ, Mouy R, Bismuth C, Bourdon R, Scherrmann JM, 1990, Toxicokinetics of paraquat in humans, Hum Exp Toxicol, 9, 1, 5-12.

27. Jain A, Martensson J, Stole E, Auld PAM, Meister A, 1991, Glutathione deficiency leads to mitochondrial damage in brain, Proc Natl Acad Sci USA, 88, 1913-7.

28. Jovanovic M, Malicevic Z, Jovicic A, Djukic M, Ninkovic M, Jelenkovic A et al., 1997, Selective sensitivity of the striatum to oxidative stress, Vojnosanit Pregl, 54, 33-43.

29. Kang MJ, Gil SJ, Koh HC, 2009, Paraquat induces alternation of the dopamine catabolic pathways and glutathione levels in the substantia nigra of mice, Toxicol Lett, 188, 2, 148-52.

30. Kannan R, Kuhlenkamp JF, Jeandidier E, Trinh H, Ookhtens M, Kaplowitz N, 1990, Evidence for carrier-mediated transport of glutathione across the blood-brain barrier in the rat, $J$ Clin Invest, 85, 2009-13.

31. Kannan R, Kuhlenkamp JF, Ookhtens M, Kaplowitz N, 1992, Transport of glutathione at blood-brain barrier of the rat: inhibition by glutathione analogs and age-dependence, $J$ Pharmacol Exp Ther, 263, 964-70.

32. Kannan R, Mittur A, Bao Y, Tsuruo T, Kaplowitz N, 1999, GSH transport in immortalized mouse brain endothelial cells: evidence for apical localization of a sodium-dependent GSH transporter, $J$ Neurochem, 73, 390-9.

33. Kannan R, Yi JR, Tang D, Li Y, Zlokovic BV, Kaplowitz N, 1996, Evidence for the existence of a sodium-dependent glutathione (GSH) transporters, J Biol Chem, 271, 9754-8.

34. Kehrer J, Lund L, 1994, Cellular reducing equivalents and oxidative stress, Free Radic Biol Med, 17, 1, 65-75.

35. König JFR, Klippel RA, 1963, The rat brain, in: The Williams and Wilkins Company editors, A stereotaxic atlas of the forebrain and lower parts of the brain stem, Baltimore, USA, 53.

36. Kušić R, Raičević B, Spasić P, Ćosić V, Matunović A, 1974, Klinička i patološka zapažanja u trovanjima parakvatom, Vojnosanit Pregl, 31, 397-9.

37. Leaver MJ, George SG, 1998, A piscine glutathione S-transferase which efficiently conjugates the end-products of lipid peroxidation, Marine Environ Res, 46, 1-5, 71-4.

38. Lestaevel P, Agay D, Peinnequin A, Cruz C, Cespuglio R, Clarençon D et al., 2003, Effects of thermal injury on brain and blood nitric oxide content in the rat, Burns, 29, 557-62.

39. Lewinson E, Gressel J Benzyl, 1984, Viologen-mediated counteraction of diquat and paraquat phytotoxicities, Plant Physiol, 76, 125-30.

40. Lowry OH, Rosenbrough NJ, Farr AL, Randall RJ, 1951, Protein measurement with the Folin phenol reagent, J Biol Chem, 193, 265-75. 
41. Maral J, Puget K, Michelson AM, 1977, Comparative study of superoxide dismutase, catalase and glutathione peroxidase levels in erythrocytes of different animals, Biochem Biophys Res Commun, 77, 1525-35.

42. McCormack AL, Atienza JG, Johnston LC, Andersen JK, Vu S, Di Monte DA, 2005, Role of OS in paraiquat induced dopaminergic cell degenaration, J Neurochem, 93, 1030-7.

43. Meister A, 1988, Glutathione metabolism and its selective modification, J Biol Chem, 263, 33, 17205-8.

44. Meister A, 1991, Glutathione deficiency produced by inhibition of its synthesis, and its reversal; applications in research and therapy, Pharmacol Ther, 51, 155-94.

45. Mieyal JJ, Gallogly MM, Qanungo S, Sabens EA, Shelton MD, 2008, Molecular mechanisms and clinical implications of reversible protein S-glutathionylation, Antioxid Redox Signal, 10, 11, 1941-88.

46. Mieyal JJ, Gallogly MM, Qanungo S, Sabens EA, Shelton MD, 2008, Molecular Mechanisms and Clinical Implications of Reversible Protein S-Glutathionylation, Antioxid Redox Signal, 10, 11, 1941-88.

47. Misra I, Grifth OW, 1998, Expression and purification of human g-glutamylcysteine synthetase, Prot Expr Purifc, 13, 268-76.

48. Mølck AM, Friis C, 1997, The cytotoxic effect of diquat to isolated renal proximal tubular segments from rabbits, Toxicology, 122, 123-32.

49. Ninkovic M, Jovanovic M, Malicevic Z, Jelenkovic A, Djukic M, Vasiljevic I, 2003, Antioxidative effect of nerve growth factor (NGF) in rat thalamus after quinolinic acid-induced neurotoxicity, Acta Vet (Beograd), 53, 2-3, 77-85.

50. Ninkovic M, Malicevic Z, Stojanovic D, Vasiljevic I, Jovanovic M, Djukic M, 2008, Brain stem and thalamus antioxidative defense in experimental sepsis, Acta Vet (Beograd), 58, 2-3, 129-37.

51. Nivière $V$, Fontecave $M, 1995$, Biological sources of reduced oxygen species, in: Favier $A$, editor, Analysis of Free Radicals in Biological Systems, Basel Switzerland: Birkhauser, 11-20.

52. Noack H, Possel H, Rethfeldt C, Keilhoff G, Wolf G, 1999, Peroxynitrite mediated damage and lowered superoxide tolerance in primary cortical glial cultures after induction of the inducible isoform of NOS, Glia, 28, 1, 13-24.

53. Olafsdottir K, Reed DJ, 1988, Retention of oxidized glutathione by isolated rat liver mitochondria during hydroperoxide treatment, Biochim Biophys Acta, 377-82.

54. Ondaraza R, Abney $R, 1970$, On the active site of the of the NADPH-dependent CoA-SS-glutathione reductase from yeast and rat liver, FEBS letters, 7, 3, 227-30.

55. Pastore A, Federici G, Bertini E, Piemonte F, 2003, Analysis of glutathione: implication in redox and detoxification, Clinica Chimica Acta, 333, 19, 3921.

56. Prado H, Diaz P, Ortiz JL, Baeza A, 2004, Polarographic determination of $\mathrm{Km}$ and Vmax of glutathione reductase, Curr Separ, 20, 4, 117-20.

57. Richman PG, Meister A, 1975, Regulation of g-glutamylcysteine synthetase by nonallosteric feedback inhibition by glutathione, $J$ Biol Chem, 250, 1422-6.

58. Robbe WCIII, Meggs WJ, 2004, Insecticides, herbicides, rodenticides, In: Tintinalli JE, Kelen GD, Stapczynski JS, Ma OJ, Cline DM, editors, Emergency Medicine: A Comperhensive Study Guide, 6th ed New York, NY: McGraw-Hill, Chap 182.

59. Roušar T, Kucera O, Lotková H, Cervinková Z, 2012, Assessment of reduced glutathione: Comparison of an optimized fluorometric assay with enzymatic recycling method, Analyt Biochemi, 423, 236-40.

60. Schafer FQ, Buettner GR, 2001, Redox environment of the cell as viewed through the redox state of the glutathione disul?de/glutathione couple, Free Radic Biol Med, 30, 1191-212.

61. Schraufstatter IU, Hinshaw DB, Hyslop PA, Spragg RG, Cochrane CG, 1985, Glutathione Cycle Activity and Pyridine Nucleotide Levels in Oxidant-induced Injury of Cells, J Clin Invest, 76, 1131-9.

62. Shaik IH, Mehvar R, 2006, Rapid determination of reduced and oxidized glutathione levels using a new thiol-masking reagent and the enzymatic recycling method: application to the rat liver and bile samples, Anal Bioanal Chem, 385, 105-3. 
63. Smith CV, 2005, Compartmentalization of redox regulation of cell responses, Toxicol Sci, 83, 1, 1-3.

64. Sommer D, Fakata KL, Swanson SA, Stemmer PM, 2000, Modulation of the phosphatase activity of calcineurin by oxidants and antioxidants in vitro, Eur J Biochem, 267, 8, 2312-22.

65. Stevens JT, Summer DD, 1991, Classes of Pesticides, In: Hayes WJ, Laws ER, editors, Handbook of Pesticide Toxicology: Herbicides, NY: Academic Press, Chap 3.

66. Tawara T, Fukushima T, Hojo N, Isobe A, Shiwaku K, 1996, Effects of paraquat on mitochondrial electron transport system and catecholamine contents in rat brain, Arch Toxicol, 70, 9, 585-9.

67. Tretter L, Répássy R, Adam-Vizi V, 2003, Endogenous glutamate contributes to the maintenance of glutathione level under oxidative stress in isolated nerve terminals, Neurochem Int, 42, 393-400.

68. Wade LA, Brady HM, 1981, Cysteine and cystine transport at the blood-brain barrier, J Neurochem, 37, $730-4$

69. Widdowson PS, Farnworth MJ, Upton R, Simpson MG, 1996, No changes in behaviour, nigro-striatal system neurochemistry or neuronal cell death following toxic multiple oral paraquat administration to rats, In: Chemical Propertis, Toxicity and Biodegradation of Paraquat, Hum Exp Toxicol 7, 583-91.

70. William A Banks, 2009, Characteristics of compounds that cross the blood-brain barrier, BMC Neurology, 9(Suppl 1):S3 doi:101186/1471-2377-9-S1-S3.

71. Wolfgang GH, Jolly R, Petry T, 1991, Inhibition of diquat-induced lipid peroxidation and toxicity in precision + cut liver slices by novel antioxidants, Toxicol Appl Pharmacol, 108, 2, 321-9.

72. Wu G, Fang YZ, Yang S, Lupton JR, Turner ND, 2004, Gluthatione metabolism and its implication for health, J Nutr, 134, 489-92.

73. Yoshimura K, Iwauchi Y, Sugiyama S, Kuwamura T, Odaka Y, Satoh T et al., 1982, Transport of Lcysteine and reduced glutathione through biological membranes, Res Commun Chem Pathol Pharmacol, 37, 2, 171-86.

74. Zeevalk GD, Razmpour R, Bernard LP, 2008, Glutathione and Parkinson's disease: is this the elephant in the room? Biomed Pharmacother, 62, 4, 236-49.

75. Zlokovic BV, Mackic JB, McComb JG, Weiss MH, Kaplowitz N, Kannan R, 1994, Evidence for transcapillary transport of reduced glutathione in vascular perfused guinea-pig brain, Biochem Biophys Res Commun, 201, 402-8.

\title{
ULOGA GLUTATIONSKOG CIKLUSA U NEUROTOKSIČNOSTI DIKVATA: ISPITIVANO PIRMENOM INTRASTRIJATALNOG PREDTRETMANA SA GLUTATION REDUKTAZOM
}

\author{
ĐURĐEVIC D, ĐUKIĆ MIRJANA, NINKOVIĆ MILICA, STEVANOVIĆ IVANA, JOVANOVIĆ \\ MARINA i VASIĆ UNA
}

\section{SADRŽAJ}

Mehanizmi neurotoksičnosti dikvata (DK) su nepoznati, mada se zna da je sistemska toksičnost posredovana reakcijama slobodnih radikala. Uloga glutationskog ciklusa je isptivana primenom glutation reduktaze (GR) u predtretmanu trovanja DK. Wistar pacovi su korišćeni i testirana jedinjenja intrastrjiatalno (i.s.) primenjena u jednokratnoj dozi. Ukupni glutation (tGSH), glutation-disulfid (GSSG) i aktivnost glutation peroksidaze $\left(\mathrm{GP}_{\mathrm{x}}\right)$ su mereni u selektivno osetljivim regionima mozga (strijatum, hipokampus i korteks), 30. minuta, 24. sata i 7. dana posle tretmana. 
Acta Veterinaria (Beograd), Vol. 63, No. 2-3, 159-175, 2013.

Rezultati netretiranih (intaktna grupa) i lažno operisanih pacova se ne razlikuju statistički. Vremensko i prostorno širenje oksidativnog stresa je potvrđeno kod ispitivanih moždanih struktura. Mortalitet (30-40\%, u roku od 24 časa) i znaci letargije su uočeni u samo u DK grupi. Statistički povećana aktivnost $\mathrm{GP}_{\mathrm{x}}$, kao i odnosa GSSG/GSH u ispitivanim moždanim strukturama tokom eksperimenta, potvrđuje oksidativno narušenu ravnotežu i oštećenja moždanog tkiva. Predtretman i.s. sa GR je ispoljio neurozaštitni efekat od neurotoksičnosti DK, bazirano na preživljavanju životinja, odsustvu letargije i smanjenoj aktivnost $\mathrm{GP}_{\mathrm{x}} \mathrm{i}$ odnosa GSSG / GSH ispitivanih moždanih struktura tokom eksperimenta, u odnosu na DK grupu. Naši rezultati ukazuju da je oksidacija GSH ključna za smanjenje antioksidativne odbrane od DK neurotoksičnosti. 